\title{
THE ROLE OF EDUCATION AND CULTURE IN THE SOCIAL CONSTRUCTION OF THE EUROPEAN UNION*
}

\author{
Sertan AKBABA**
}

\section{Abstract:}

As a dynamic and ongoing process European integration has faced many difficulties so far. Nevertheless through widening and deepening the European Union (EU) is trying to expand its competence within different policy areas. Two of these areas, namely education and culture have close links to today's highly debated subject of 'integration of the people' within the EU project.

The aim of this paper is to analyze the role, the effects and the aims of the education and cultural fields in creating the 'peoples of Europe' project. In the field of education, the EU has been pursuing the aims of the Bologna Process to establish the European Higher Education Area until 2010. Closer cooperation and protection of the common cultural heritage of Europe owns are the main concerns of the cultural policy. These two policy areas also support the efforts to create the 'Peoples of Europe' project which was introduced for the first time in the Tindemanns report. The programmes introduced under education and culture (such as student exchange, student mobility, and cultural action programmes) are opening the way for intercultural dialogue, harmonization of people, creating the feeling of belonging to the same community, strengthening EU Citizenship, and spreading the 'we' feeling across Europe. In short, these two policy areas interact with the aim of supporting the social construction of the EU.

Keywords: Education policy, Culture, Cultural diversity, Social Cohesion, EU Citizenship.

\footnotetext{
"This article is a reformulation and summary of the author's M.Sc. thesis submitted to the European Union Institute of Marmara University.

** Ph.D candidate, Marmara University, European Union Institute, Department of EU Politics and International Relations.
} 


\section{Özet:}

Avrupa bütünleşme süreci bazı zorluklarla karşılaşmasına rağmen gerek genişleme gerekse de derinleşme politikalariyla yoluna devam etmektedir. $\mathrm{Bu}$ bütünleşme süreci içinde parasal birlik ve tek pazar tam başartya ulaşılmış alanlar olarak öne çıkmaktadır. Ancak bu iki politika alanın gölgesinde kalan pek çok konu da Avrupa Birliği'nin (AB) geleceğini şekillendirmektedir. AB özellikle Maastricht antlaşmastyla politika alanlarını geniş bir yelpazeye yaymışıtır. Bu alanlardan ikisi olan eğitim ve kültür özellikle günümüzde $A B$ ve kamuoyunda tartışllan, insanların veya toplumların bütünleşmesi ya da uyumu nasll sağlanacaktır sorusuyla yakından ilintilidir. $B u$ sorun $A B$ Anayasasının referandum süreci ve sonrasında yaşanan başarısızlıkla daha da önem kazanmıştır. Üye ülkelerin toplumları ile AB'nin kurumları arasındaki kopukluk ve uçurum referandumla ilgili tartışmalarla iyice gün yüzüne çıkmışır. Eğitim ve kültür politikalarının $A B$ iç̧inde iki önemli amacı olduğu söylenebilir. Bunlardan ilki kendi alanları doğrultusunda hedeflerini gerçekleştirmektir. $\mathrm{Bu}$ hedefler kisaca belirtmek gerekirse eğitim alanında Avrupa yüksek ögretim alanı projesini hayata geçirmek, kültür alanında ise Avrupa'nın sahip olduğu ortak kültür mirasina sahip çıkmak ve bunu yaymaktır. Bunların dışında yukarıda sözü edilen eğitim ve kültür politika alanları ikinci bir amacı üstlenmiştir. Bu görev AB'nin ilk defa Tindemann raporunda açıkça dile getirdiği 'Avrupa Toplumu' yaratma projesidir. Eğitim ve kültür alanları içinde başlatılan öğrenci değişim programlart, ögrenci hareketliliği aktiviteleri ya da kültür programları eğitim ve kültürün yanı sıra toplumların birbirleriyle kaynaşmasını, daha yakından tanımasını ve müşterek bir çatı altında olduklarını sürekli hatırlatma ve 'biz' duygusu içinde hareket etmelerini sağlamaktır. Bu sebeple de ortaya konan eğitim ve kültü̈rün sadece kendi alanları içinde sinırlandırlmaması gerektiği aksine çok daha geniş ve önemli bir amaca hizmet ettiğinin alt çizilmiştir. Öyle görünüyor ki AB'nin özellikle gelecekteki hedef ve beklentileri çerçevesinde ve Lizbon stratejisi gereğince 'dünyadaki en rekabetçi ve dinamik bilgi tabanl ekonomisi' olma yolundaki hedefi bu iki politika alanın yakın zamanda daha da önemli kllacaktır.

Anahtar Kelimeler: AB Eğitim Politikası, Kültür, Kültürel çeşittlilik, AB Vatandaşlı̆gl. 


\section{Introduction}

The ongoing EU integration is giving birth to a variety of highly debated subjects, each tackling a different dimension within the EU framework, which one of them appears to be the question of 'how this community will be transformed into a 'civil society'. This debate mostly circles around creating the European consciousness for deeper integration among the EU citizens. Certainly, this debate dates back to the 1970's starting with the Tindemanns Report which suggested the importance of transforming the 'Technocrats of Europe' into a 'Peoples of Europe' project. Especially after the failure of the ratification process of the Constitutional Treaty both scholars and politicians have started questioning this absence, as the question appeared to be "how and under which conditions will the integration of the people will be achieved'. The EU has always been criticized for showing a lack in coming closer to the man on the street; although this was underlined with importance in both the Rome and Maastricht Treaties. The most important criticism of this argument is that the EU is driven by the elites, also known as technocrats or eurocrats. For instance, Shore argues that "European citizenship was invented primarily to placate an alienated populace by promoting feelings of belonging to what was and remains, a highly elitist, paternalistic and technocratic project of European construction" (Shore, 2004:34). Börzel \& Risse (2002) prefer naming them 'change agents' especially in the context of Europeanization (cited in Seidendorf, 2003:3). I will prefer naming them all as instrumentalists. What this paper argues, is actually how and under which conditions education and culture have shaped this process of establishing notions for creating consciousness among the people of Europe. In that sense, it could be argued that both education and culture are ways of indirectly, but consequentially, affecting this process. This dimension can be defined as strengthening EU citizenship through the education and cultural activities of the Union.

\section{Building Europe through Education and Culture}

Throughout the history, education lies at the core of human life. Social, economic, political and cultural activities are all closely associated with education. Moreover today's knowledge based economies require a highquality of education in many sectors. Therefore the role of education in learning and improving work-skills and in developing personal preferences is unquestionably significant. The point which should be noted here is that, education is endless and in today's globalizing world its importance in daily life is increasing due to new developments in the fields of science and 
technology. The following definition of education can describe well the role of education in creating and conveying knowledge and daily life habits through the generations. Education can formally be defined as; "The social process by which people are subjected to the influence of a selected and controlled environment so that they may attain social competence and optimum individual development" (Oğuzkan, 1997:2). Education, in a very broad context encompasses several meanings and can take place in different forms depending mainly on the target group and time-period. However they all include certain key features such as development and passing knowledge from one generation to another. Contemporary understanding of education further necessitates a multifaceted vision. The $\mathrm{EU}$ has so far tried to establish such a base for its education policy.

Education can simply be described as a learning process. The definition of education shows differences in social level of societies and nations. Allin-all the word education is strictly related with the terms 'develop', 'knowledge', and 'character' of a student or the students (Yero, 20012002:1). Unlike past understandings, education does not merely indicate the learning or studying of students from primary school up to higher education. Contrary to the past understanding nowadays education can be defined in a wider context including different types of education such as 'lifelong learning', 'adult education' and 'vocational training'. The EU through its programmes and common objectives shows that it has adopted a similar approach as well. For instance, with its wide field of education programmes (Erasmus for higher education, Grundtvig for adult education, Minerva for open and distance learning, or Comenius for school education etc.) the EU has established programmes for different groups at any age to be able to participate. But within this paper the roles of both education and culture with their second mission of bringing people more closely to each other will be discussed.

Education is one of the most important predictors usually, in fact, the most important predictor - of many forms of social participation - from voting to associational membership, to chairing a local committee to hosting a dinner party to giving blood. The same basic pattern applies to both men and women and to all races and generations. Education, in short, is an extremely powerful predictor of civic engagement (Campbell, 2006:26).

The aforementioned role of education is also very crucial tool for the European Union. It seems that the $\mathrm{EU}$ has been using its education 
programmes for the last twenty years as an instrument for strengthening both its integration process and worldwide economic competitiveness. Initially, education and cultural policies have gained importance in the early 1970 's within the EU and have developed not just to function in their own fields, but have another important function in helping to create 'an ever closer Union among the people of Europe', which was clearly stated in the Maastricht Treaty. Therefore, the main argument of this paper is that, education and cultural policy areas of the EU are not limited to activities of teaching, developing skills, or improving cultural habits. These areas are also related to creating and enhancing social cohesion within the EU. However, it may be better to name these as common education \& cultural objectives of the EU. Or it may be defined as a platform for the EU Member States to share or exchange there ideas in the realm of education and culture, as the EU still lacks a common education and cultural policies. The awareness of creating an education policy within the Union started in the 1970's which is known as an era of stagnation within the European Community. The cooperation in education, later followed by the efforts to cooperate on cultural policy were seen as ways of coping with stagnation. The main reasons for establishing such policy areas in the EU rest on the values of solidarity, dignity, prosperity, and diversity. What the EU aimed for during that period was to establish a solid basis for strengthening social cohesion through these policy areas.

In order to illustrate the actions of the EU in education and policy making in this field, it is necessary to outline the historical process of education within the EU. The education field found its legal basis within a separate chapter in the Maastricht Treaty (Articles 149 and 150), but the first major steps taken in the higher education field were in the well known Sorbonne Declaration (1998) for closer cooperation in the field of higher education in Europe. Although the process was launched with only four Member States (namely France, Germany, Italy, and the United Kingdom), just one year later with the start of the Bologna Process (BP) in 1999, the participating number of countries increased to 29. With the Bergen Summit (2005) the total number of participating countries is now 45, both from both in and outside of the EU. Certainly the aim of the BP was for settling coordination among countries in there education systems in order to provide convergence at the European level, and for creating a European space for higher education and increasing the international competitiveness of European Higher Education Area (EHEA) (Corbett, 2005:194-201).

In addition to the higher education objectives, there is also a need to look at the cultural area and to focus on the role of these fields in the social 
construction of the EU. Culture can be defined as; "the system of shared beliefs, values, customs, behaviors, and artifacts that the members of society use to cope with their world and with one another, and that are transmitted from generation to generation through learning'(Cornwall Compact, 2006:5). Culture has gained importance especially with the formation of the Nation States and became a policy area for states in protecting and for developing there own heritage. Within EU the importance of culture came on to the agenda with the Solemn Declaration (1983) which stated "closer cooperation on cultural matters, in order to affirm the awareness of a common cultural heritage as an element in European Identity" (Solemn Declaration, 1983:25). The cultural area of education was taken into the Maastricht treaty under a separate chapter (Article 128 of TEU) where it found its legal basis. From then on, there have been programmes and activities established in creating awareness of the cultural heritage Europe owns. The well known programmes are the Culture 2000 programme and the European Capitals of Culture. Within the EU project what makes culture indispensable, is its role with the other policy sectors in which it interacts as cement for strengthening them all together. The importance of culture within this realm has been briefly defined as "Problems associated with social and labour market policies, or the healthcare and the education systems cannot be successfully addressed as long as culture is treated as a luxury and not as a source of development' (Andras Bozoki, speech by Minister of Culture of Hungary, retrieved on 10.02.2007:6). That is why the politicians, both at national and EU level and the elites alongside with nongovernmental organizations have to concentrate on how this impact of culture could be carried to the forefront within the EU integration.

These policy areas do differ from others when compared to the decision making process. Both education and cultural realms are established on voluntary cooperation within the EU context. The decision making process holds an intergovernmental view with a new process developed for decision making in sensitive areas like education and culture, which is the Open Method of Coordination (OMC). This method increases co operation on one hand and diversity and competition on the other. OMC can be defined as agreeing on policy issues with voluntary cooperation where it is up to the Member States to be involved or not to the taken decisions as neither there are sanctions nor binding decisions for the Member States. This decision making process can be defined as a way of benchmarking and more like a learning from process among the participating states (Radaelli, 2003:7-9) 


\section{Cultural Diversity, Education and Citizenship in the $\mathrm{EU}$}

Being a multicultural, multiethnic, and multilingual entity, managing cooperation and integration within the areas education and culture are not as easy for the Member States as it was in 1951 for coal and steel. But it is evident that the EU is continuously expanding itself both through widening and deepening. The idea of widening EU policies and activities mainly took place at the beginning of the 1990's with the Maastricht Treaty, where the EU started involving different policy areas, one of which was the cultural policy of the EU.

Bringing different cultures to the same platform for sharing different values, traditions, and languages would serve better for Europe as this new dimension was introduced under the term 'cultural diversity' within the EU, stated in the Treaty on the EU Article 128. Diversity is defined as "focusing on treating people as individuals, rather than focusing on groups of people. It means recognizing individual differences that are a natural part of society" (Cornwall Compact, 2006:5). Certainly bringing these two terms together as 'cultural diversity' has been a mission of the EU to respect these values of the Member States but at the same time to create a common platform for sharing them which afterwards became the goal of the EU to integrate through 'Unity in Diversity'. Europe has a common cultural heritage and this cultural heritage is seen as a vehicle for creating cultural identity. Accordingly under the title of 'Reducing linguistic and cultural obstacles' which was stated in the Green Paper $1996^{1}$ from the Commission

${ }^{1}$ European Commission, The obstacles to transnational mobility, Green Paper, 1996 ,

- Learning at least two Community languages has become a precondition if citizens of the EU are to benefit from occupational and personal opportunities open to them in the Single Market.

- All mobility actions should be preceded by a period of linguistic preparation.

- Any training should be accompanied by cultural preparation and an initiation to living and working practices in the host country.

- Pilot actions should be developed in Member States to make young people in particular aware of 'European citizenship' and to increase their respect for cultural and social differences.

- The national bodies in charge of activities under Community programmes should provide still more help for people wishing to undertake transnational training in a Member State whose language is "less widely used and taught", retrieved: 11.04.2007, from http://old.certh.gr/libfiles/PDF/MOBIL-67-education_mobility_ obstacles_gp_COM_96_462.pdf. 
that Europe was a continent sharing the same cultural aspects on the same platform and at the same time developing them with no discrimination.

The term 'social cohesion' is the key word for the development of these policy areas which have been stated in the Commission report in $1997^{2}$. Apparently the term social cohesion carries importance within these policy fields. However, according to Jane Jenson (1998) it might be better to say a 'socially cohesive society' instead of using social cohesion, in which she further states that the elements which strengthen cohesion are belonging, participation, recognition, inclusion and legitimacy (Jenson (1998) cited in Spoonley, Peace, Butcher, O'Neill, 2005:88). These elements are also what the Union is willing to fulfill in order to bring the peoples of Europe more closely together without causing polarization. Trying to spread the feeling of 'belonging' among the citizens of EU the Union has produced several programmes through which ordinary people could participate in actions carried out under education and cultural policies. The point here which must be underlined is of both education and cultural policy areas being used as tools in building the social construction of Europe which was first laid down in the Commissions Report in 1996 'Report on the Consideration of Cultural Aspects in European Community Action' (European Commission, (COM 160) 1996:2) and the cultural policy using 'Education as European Cultural Construction' (Lawn, 2003:327).

There is definitely a close relation between these policy areas within the EU context as education programmes namely the student exchange programmes are used as a tool for spreading the awareness of sharing a common cultural heritage which Europe owns as a whole. Such example may be given as the education programmes of the EU are given the names of the symbols of the common heritage within the Europe. For example the

\footnotetext{
${ }^{2}$ If Europe is to remain at the driving edge, economic and political progress must be complemented by offering a "European vision"' to Europe's young people. All young Europeans must be guaranteed access to education and training culminating in acquisition of a foundation of recognized basic knowledge and skills and access to guidance and counseling at critical moments of transition. Maintaining Europe's social cohesion hinges on the following actions being taken at the EU level: affirm the need for intercultural schools to transmit the common values on which

European civilization is founded and help devise disseminate ways of enabling Europe's young people to play a fuller role as European Citizens;... ], retrieved: 20.05.2007, from http://eric.ed.gov/ERICDocs/data/ericdocs 2 sql/content_storage 01/0000019b/80/16/ba/67.pdf.
} 
Grundtvig programme is named after Nikolai Frederik Severin Grundtvig3. Another example is the Comenius programme which is named after a Czech philosopher, and pedagogue; Johann Amos Comenius ${ }^{4}$. There are several more examples such as the names of Socrates, Erasmus, and Minerva for other programmes in this field.

It has been fifty years since the signing of the Treaty of Rome and the ongoing EU project is expanding through widening and deepening, but the question is, where does the integration of the people within the EU context through achieving the goal of harmonization stand? This paper aims to analyze the questions of what is the meaning of being a European citizen and how it could be achieved in creating a European society or 'Peoples of Europe' project and how education and cultural policy areas are shaping this harmonization process. The education and cultural objectives of the EU help create the social cohesion between the Member States of the Union the 'peoples' Europe with the values of freedom, peace, law, prosperity, diversity, and solidarity.

The education and cultural activities of the Union are used as tools in order to strengthen the EU citizenship and the harmonization of the societies, especially after the recent enlargements in 2004. With the accession of 10 new Member States a great increase of cultural, social and linguistic diversity with a total population of 455 million (Monnier, 2004:316) became obvious. The further accessions of Romania and Bulgaria in 2007 increased the population even more. Therefore there are two important dimensions to be analyzed within this context that are the importance of and the means to strengthen cultural diversity within the EU.

\footnotetext{
${ }^{3}$ Nikolai Frederik Severin Grundtvig: A Danish clergyman and writer who is regarded as the founder of the Nordic tradition of "learning for life". His "folk high school" concept was based on the idea that education must be available to all citizens throughout life and should encompass not only knowledge but also civic responsibility, personal and cultural development. Retrieved: 25.06.2007, from http://ec.europa.eu/education/programmes/llp/grundtvig/index_en.html.

${ }^{4}$ A century before the Enlightenment, Comenius (1592-1670), born in what was today the Czech Republic, was a theologian, philosopher, and pedagogue who believed that only through education could man achieve his full potential and lead a truly harmonious life. He was one of the founding fathers of modern education, but, having lived through the period of the Thirty Years' War (1618-1648), retrieved: 25.06.2007 from; http://ec.europa.eu/education/programmes/lp/comenius/morea bou_en.html.
} 
The thought of developing and strengthening cultural diversity in the EU dates back to the 80's immediately after the European Council meeting in Fontainebleau, where an ad-hoc working group was created under Pietro Adonnino to improve free movement of persons with regard to student exchanges programmes, mutual recognition of diplomas, and also to start the use of Vocational Training certificates for all qualified workers. These decisions later became known as the 'Adonnino Recommendations' for the creation of 'peoples' Europe. The working group submitted its first report to the European Council in 1985 under the title of 'A Peoples' Europe (Adonnino Recommendations, 7/85: 12-14).

The context here was to prepare a paper on what was to be done in the fields of education and culture for bringing the citizens of Europe closer to each other and to the institutions of EU. Certainly this was not the first time the EU attempted to develop such activities or policies. Before the Adonnino working group the Janne Report underlined the need to improve such approaches in certain fields though gaining not much attention in those days. What the Janne Plan included was the goal of harmonization of the educational policies of the Member States creating an Education and Cultural Council and specifying the responsibilities of the Commission in this strategy which would be a model of lifelong learning called 'Education Permanente" and the promotion of foreign languages, and staff and student exchanges (Field, 1998: 35-38).

Another point which should be underlined in the field of culture and cultural activities of the Union with regard to education is that these activities are being held under the common means of Europe. There are certainly many reasons for specifying Europe rather than the EU in these policy areas. The first reason is the education and cultural actions also include non-EU Member States such as the European Economic Area (EEA) countries or the EU candidates and even countries which do not seek an EU membership. The second reason for the use of 'Europe' is that a continent sharing many cultural values in common can not be limited with the EU. The awareness of the cultural heritage and sharing of it was first mentioned in the Council of Europe which dated back to 1954 of the

\footnotetext{
${ }^{5}$ The Department of Further Education ( Direction de l'Education Permanente D.E.P.), founded in 1974, is part of the Université de Picardie Jules Verne (U.P.J.V.) which deals with organizing, coordinating and overseeing adults in further education, retrieved from: http://www.dep.u-picardie.fr/accueil/english version/missions.php, 15.06.2007.
} 
European Cultural Convention ${ }^{6}$ laying down both the importance of the cultural heritage which the countries of Europe share and the way to develop, protect, and foster it.

The cultural policy of the EU was created with all these developments. Certainly culture in the context of the EU can not be observed alone. Both culture and education are strictly connected with each other where the education action programmes of the EU are used as tools in order to share the common cultural heritage and develop it in certain fields for further cooperation. This was also stated in the decision of the Parliament and the Council on establishing the Culture 2000 Programme; "Culture has an important intrinsic value to all people in Europe, is an essential element of European integration and contributes to the affirmation and vitality of the European model of society and to the Community's influence on the international scene." (No.508/2000/EC, Official Journal of the European Communities, L63:1). As indicated in this decision culture is regarded as an element for further integration of the Union and for bringing a European societal model across Europe.

At this point a concise theoretical framework may help to understand what the EU is trying to achieve with all these action and measures. The actions carried out under both education and culture policies of the Union may be explained through the Constructivist theory. According to this theory integration can be achieved by creating a common platform between states and that can be realized by giving importance to social elements such as ideas, knowledge, cultural values and in a few cases identity, such as the EU in aiming to do in the field of its social policies which include both

${ }^{6}$ European Cultural Convention, 19.XII.1954; Considering that the aim of the Council of Europe is to achieve a greater unity between its members for the purpose, among others, of safeguarding and realizing the ideals and principles which are their common heritage; Considering that the achievement of this aim would be furthered by a greater understanding of one another among the peoples of Europe;

Considering that for these purposes it is desirable not only to conclude bilateral cultural conventions between members of the Council but also to pursue a policy of common action designed to safeguard and encourage the development of European culture;

Having resolved to conclude a general European Cultural Convention designed to foster among the nationals of all members, and of such other European States as may accede thereto, the study of the languages, history and civilization of the others and of the civilization which is common to them all, European Cultural Convention Paris, 19.XII.1954, retrieved from; http://conventions.coe.int/Treaty/en/Treaties/ Word/018.doc, 15.04.2007. 
education and culture. As one of the main assumptions of the theory is that world politics occurs in an international society and not just in an international system. Certainly these are the methods for improving the citizenship of the Union which were included in the Maastricht Treaty which underlines the urgency for developing European culture and diversity and the areas covered under "Citizens for Europe" programme with the objectives of;

Giving citizens the opportunity to interact and participate in constructing a more united Europe. Forging a European identity, based on recognized common values, history and culture. Enhancing mutual understanding between European citizens respecting and celebrating cultural diversity, while contributing to intercultural dialogue. Bring people from local communities across Europe together to share and exchange experience, opinions and values, to learn from history and to build for the future. Foster action, debate and reflection related to European citizenship through cooperation between civil society organizations at European level, Make the idea of Europe more tangible for its citizens by promoting and celebrating Europe's values and achievements, while preserving the memory of its past, Encourage the balanced integration of citizens and civil society organizations from all Member States, contributing to intercultural dialogue and bringing both Europe's diversity and unity to the fore, with particular attention to the activities with Member States which joined the EU recently (European Commission, (SEC 442) 2005:7-9).

As the aforementioned statement clearly puts forward the Citizens for Europe programme aims to harmonize the societies across Europe through intercultural dialogue. The objective of social construction of the EU is based on achieving this goal among the societies interacting with each other.

Basically constructivism argues that the theory through Cognitivism which is derived from constructivism lies in the roles of subjective factors such as culture, knowledge, ideas norms, and values which should be based on mutual understanding and the value of sharing. According to social constructivism the interaction between states is not only material but also social (Checkel, 1998:324-326). Within the EU the education and cultural activities of the Union, besides serving developments in there own field, 
also serve to improve creating the cultural identity or sharing social values and norms which will lead to the People's Europe project.

Constructivism might be seen as a heavy term when placed within the EU context since its aim of deeper integration with the goals of reconstruction of the identity and formation of a political community sharing the same interests have become more difficult to reach in today's EU especially after the ratification process of the Constitutional Treaty in several Member States. It is necessary for further steps to be taken by the EU. This can be done with the help of different policy areas serving this goal particularly with the education policy. This shift is described as the changing role of EU education policy (Walkenhorst, 2005:7).

There are different scenarios about how the social construction of EU or (with a wider term) Europe might be achieved. According to Ifversen the central theme of the project must first be put forward. He therefore articulated that concepts such as 'national culture' or a 'civilization' or a 'construction' or a 'deconstruction' of European culture could be used to define today's Europe (Ifversen, 2002:8). Certainly these concepts are closely related to each other. However it seems that the concept of Europe as a construction can provide the best explanation for the importance of education in higher education and cultural policy. This concept can indeed pave the way for the common goal of creating a wider Europe.

What the EU aims to create can be examined in two interrelated objectives the first of which is bringing the people of Europe closer to each other. The second objective is bringing the people more closely to the EU institutions for a deeper integration. The EU is trying to realize the first objective through actions and programmes encouraging people to get to know each other better. Bringing citizens of EU closer to the institutions as the second objective is to be accomplished through information and creating awareness among the public. This objective was stated for the first time in the Treaty on the EU under the chapter of 'Citizenship of the Union' in Article $8^{7}$. This was the first time citizenship entered into the Treaty basis.

\footnotetext{
${ }^{7}$ TEU, Article 8;

1. Citizenship of the Union is hereby established. Every person holding the nationality of a Member State shall be a citizen of the Union.

2. Citizens of the Union shall enjoy the rights conferred by this Treaty and shall be subject to the duties imposed thereby.

Provisions Amending the Treaty establishing the European Economic Community with a view to establishing the European Community, retrieved on 18.04.2007 from: http://www.eurotreaties.com/maastrichtec.pdf.
} 
The citizenship of EU entering the Treaty was a great step towards achieving the goal of an 'ever closer union among the people of Europe' but this did also bring a dilemma on how could citizenship be mentioned within an entity which is actually not a state. The citizenship of the EU aimed at protecting the rights and interests of the nationals of the Member States through EU citizenship. After the Treaty on the EU, the Treaties of Amsterdam and Nice did not bring significant amendments regarding citizenship. But there were indirect references in the Treaty of Amsterdam with regard to EU citizenship such as in combating discrimination or promoting consumer rights in Articles $6 \mathrm{a}^{8}$ and $129 \mathrm{a}^{9}$ of the Treaty of Amsterdam. It is obvious that the pace of developments with regard to Treaty basis did slow down after the Maastricht Treaty.

The point here to be underlined is the use of citizenship rather than identity by the EU. Although there are heated debates on 'European identity' or 'EU identity' especially in the academic community, the EU itself avoids from using the term 'identity' rather, replacing it with the term 'citizenship'. There have been many attempts in defining or at least bringing out the term identity in a way of a common sense in a historical perspective. This was stated in the "Declaration on European Identity" which was mainly about the institutional identity of the EU (see Copenhagen European Council, 1973: Annex 11, 8-10). However it also included some elements of social identity. Nevertheless it did not mark a great success in increased awareness on the issue in the EU.

Besides the ongoing debates on identity or with a limited term cultural identity there are other terms of use in describing the interaction among the

\footnotetext{
${ }^{8}$ Treaty of Amsterdam, Article 6a;
}

Without prejudice to the other provisions of this Treaty and within the limits of the powers conferred by it upon the Community, the Council, acting unanimously on a proposal from the Commission and after consulting the European Parliament, may take appropriate action to combat discrimination based on sex, racial or ethnic origin, religion or belief, disability, age or sexual orientation, retrieved: 20.04.2007, from http://www.eurotreaties.com/amsterdamtreaty.pdf.

${ }^{9}$ Treaty of Amsterdam Article $129 \mathrm{a}$;

In order to promote the interests of consumers and to ensure a high level of consumer protection, the Community shall contribute to protecting the health, safety and economic interests of consumers, as well as to promoting their right to information, education and to organize themselves in order to safeguard their interests, retrieved: 20.04.2007, from http:/www.eurotreaties.com/amsterdam treaty.pdf. 
Member States. The aim of the social construction has also been laid down under different terms such as 'social cohesion', 'amalgamation' or 'cultural mosaics' so far. These terms should be defined in the context of EU under multiculturalism in order to explain how and why the EU is developing its actions in this field.

Starting with the term 'cultural mosaics' Shore (2006) has criticized that the concept is insufficient in explaining the foundational idea of Europe, and it should be better focusing on 'social cohesion', and the European construction and governance (Shore, 2006:7-8).

The term 'amalgamation' is another key word in explaining what today's Europe is or is not. According to Prodi it is specified as "transcultural amalgam" also loading a universal meaning within the EU context defining it as made up of elements from the different national and regional cultures (Prodi (2000) cited in Ifversen, 2002:11). In this definition it might be seen as both widening the term on one hand through conferring it to a western bloc not limiting it to only Europe and on the other hand limiting it only through cultural terms in defining the construction.

The only term 'social cohesion' here has a suitable meaning which the EU has presented under the principle of solidarity which covers a system of dialogue that minimizes the disparities and avoids polarization in creating a European society. According to Gerard Delanty "Cultural integration without a social integration view will not be able to give any results" (Delanty, 2006:13). So the question here which must be answered is how and where these education and cultural policies and activities of the Union are related with the aforementioned terms and concepts. As indicated in the first chapter the will of creating a socially cohesive society dates back to the Maastricht Treaty (with the new policy areas being introduced and laid down on a legal basis therein) for the first time.

The education policies or objectives of the EU have an important dimension with regard to socialization and employment which are great obstacles for EU to overcome in the future for further and deeper integration. The key which must be emphasized within this context is the creation of a knowledge-based society that is able to cope with both the obstacles the EU is facing inside and to cope with the affects of globalization. In the 1997 Commission report 'knowledge', 'citizenship' and 'competence' were stated as three elements of fulfilling the lifelong learning programme pointing out the intersection between education, society and economy (European Commission, (COM 678) 2001:6). Certainly these areas are closely related with each other where the education 
programmes are directly maintaining productive, highly skilled employees for the EU through exchanging knowledge amongst the Member States' people.

\section{Active Citizenship through Student Mobility}

'Student mobility' programmes are the most important tools of education and cultural projects to enhance cultural diversity and to create EU cultural identity. Student mobility is basically seen as an instrument for development, which serves both the economy and the society. The active citizenship term therefore not only refers to individual actions but also covers communication and participation between groups, networks among the Member States. These were stated in the Lisbon European Council 2000 as;

Europe's education and training systems need to adapt both to the demands of the knowledge society and to the need for an improved level and quality of employment. They will have to offer learning and training opportunities tailored to target groups at different stages of their lives: young people, unemployed adults and those in employment who are at risk of seeing their skills overtaken by rapid change. This new approach should have three main components: the development of local learning centres, the promotion of new basic skills, in particular in the information technologies, and increased transparency of qualifications (European Commission, (COM 678) 2001:6)

As understood from the above mentioned Council conclusion, education and training have effects on employment and are seen as a part of it, since they strengthen Europe's worldwide competitiveness. This objective was first defined in Lisbon 2000 with the aim of creating a knowledge-based economy and reinforcing social bonds. Thus the EU aims at deepening integration through economic and social sustainability.

According to Walkenhorst the education and cultural policies of the Union have always carried both economic and political aims. For instance during the 60's they were seen as tools for improving awareness and competing with stagnation, while in the 80's supporting the integration. However in the 90's they were regarded as tools for developing European identity and finally with the beginning of 2000 they appear as a support for citizenship in order to compete with globalization (Walkenhorst, 2005:7 Table 1.) 
This actually can be witnessed in a recent survey done in 2007. Young people (aged between 15-30) in EU Member States were asked to answer such questions as: what is the meaning of EU Citizenship and how or what makes them feel belonging to the European community? The result of the survey came out with $94 \%$ of the youth responding to the question of 'meaning of being a citizen of the EU' is 'being able to study in any EU country'. This was followed by $88 \%$ responding with the answer of 'the right to work in any EU country' (Euro barometer, 2007:29). That is to say, both education and culture are strengthening the social dimension of the integration process.

The first awareness of improving mobility was stated in the White Paper in 1995 under the title of 'Mobility' 10, and followed by the Prague Communique in 2001 under the title of 'Promoting Mobility'", which was

${ }^{10}$ White Paper, 1995, Mobility; Student mobility will be made easier. In line with the Resolution of the European Parliament and the Conclusions of the Council of Ministers (1993), any students obtaining a grant in their own country must be able, if they wish, to use it in any higher education establishment in another Member State prepared to accept them. The Commission will submit a proposal to this effect. New "masters" level courses will be devised, in cooperation with several higher education institutions through pooling human and material resources; these will lead to mutually recognized qualifications responding to the skill needs of the single market. Mutual academic and vocational recognition will be developed by the generation of the system of "credit" transfers (European Credit Transfer System - ECTS) and the application of equivalent methods to vocational training. The aim is to obtain mutual recognition of training modules, giving preference to agreements between education and training establishments and between economic sectors. The obstacles (administrative, legal and those connected with social protection) acting as a brake on exchanges of students, trainees, teachers and researchers must be removed; the Commission will work out specific proposals on the basis of guidelines in a Green Paper on these matters included in its work programme. Commission White Paper on Education and Training, Teaching and Learning, Towards the Learning Society, 1995. Retrieved: 16.01.2007, from http://europa.eu/documents/comm/white_papers/pdf/com95_590_en.pdf.

11 Prague Communiqué of the meeting of European Ministers in charge of Higher Education, Prague, 2001, Promotion of mobility; Ministers reaffirmed that the objective of improving the mobility of students, teachers, researchers and administrative staff as set out in the Bologna Declaration is of the utmost importance. Therefore, they confirmed their commitment to pursue the removal of all obstacles to the free movement of students, teachers, researchers and administrative staff and emphasized the social dimension of mobility. They took note of the possibilities for mobility offered by the European Community programmes and the progress achieved in this field, e.g. in launching the Mobility 
later repeated in the Berlin 2003 and London 2006 Summits. The conference is regarded as one of the first steps referring for the social dimension of the mobility among the Member States which is an important component for the social integration of the Union. The EU, by developing these actions carried out under certain programmes, which promote mobility, and by improving the quality of education and attracting foreign students, serves the integration of the Union with encouraging the mobility of people as well providing a platform for cultural exchange. This latter aspect can also be used as a tool to increase tolerance and understanding among different cultures, as well as to improve the image of Europe throughout the world.

Certainly the aims of the EU in higher education are also affected by the globalization which has forced the EU to shape its common objectives in this field so far. The process of higher education in Europe started with a Europeanization among the countries in Europe with the aim of 'the Europe of Universities' and continued with internationalization involving different states around the world under the terms of 'global universities' or 'transnational higher education' (Chugina, 2006:23-24).

\section{Conclusion}

In 2007 the EU celebrated its $50^{\text {th }}$ anniversary with the integration process having managed to overcome many obstacles that it has faced, and having continued to develop during this time. The EU managed to establish its institutions as well as its successes in several policy areas namely in economic and monetary affairs. But the challenge that the EU aims to cope with and overcome is the difficulty of bringing the people or societies closer to each other and of bringing the people closer to the EU itself. This difficulty was strongly evident during the ratification procedure of the Constitutional Treaty which almost resulted in catastrophe. One of the main reasons for such a result was stated as a huge gap between the EU and the people namely the man on the street. Although this deficiency was stated and a clear requirement in transforming the 'Technocrats of Europe' into 'People's of Europe' as put forward by the Tindemans report for the first time, it appears that the EU has made no significant progress in this field to date. However it does not necessarily mean that this is the end of a far reaching project. Recent developments in the fields of education and culture have indicated that 'bringing together' is a difficult task but not impossible.

Action Plan endorsed by the European Council in Nice in 2000. Retrieved: 19.06.2007, from http://www.bologna-bergen2005.no/Docs/00-Main_doc/010519 PRAGUE_COMMUNIQUE.PDF. 
There is an important intersection between the education and cultural policy areas within the EU where the culture uses the education programmes and actions as vehicles to improve and develop its own objectives. The process may be defined as a function of EU higher education which supports student mobility through its programmes so that people can explore different social and cultural heritages. This certainly will open a way for intercultural dialogue and serve the cultural objectives of the EU. Another impact is that both of the areas, education and culture, are seen as tools for the social construction of the EU which was stated for the first time in the Tindemans Report and later rephrased in the Janne Plan and White Paper of 1995. These are known to be the first progressive efforts to open the way for cooperation or at least starting the awareness among the Member States which date back to the 1970's.

This paper hence presents how the EU aims to achieve its goals of accomplishing social construction of the Union with the help of education and culture objectives. However it should be noted that the impact of these policies is not limited to the EU. These programmes are also open to third countries all over the world. The best example could be the Erasmus programme, which is the European action scheme for the mobility of university students. This was the first action programme introduced by the EU.

After recent developments, namely within the Bologna Process and finally with the Bergen Summit, the total sum of participating countries has reached the number of 45 . Therefore it can be argued that education and culture have a much broader meaning within the EU project. This paper hence also aimed to explore in which ways these policy fields could support the social construction of the EU.

Certainly the latter role of these policy areas can be divided into two spheres. In the first sphere, they function to reinforce the idea of being a European, while in the second sphere they act to support economic terms in such a way to improve the quality of labour, employment, and create a knowledge-based economy as stated in the Lisbon European Council. In other words the EU tries to maintain its social and economic sustainability within its borders. However, coping with the effects of globalization obviously necessitates the high level of competitiveness in all fields. Since increasing global competitiveness is also one of the most important goals that the EU wants to achieve, the final chapter of this paper has dealt with the questions arising from this function and questioned the future prospects for the EU in this context. 
The action programmes carried out under education and cultural fields should not be seen as accomplishments only in higher education or as exchanges of cultural experiences, but should also be seen as tools promoting active citizenship. It should be underlined with great importance that improvements to be gained within these areas directly affect the EU's strategic interests through strengthening supranational view within the EU project. The student mobility which is offered by these education and cultural programmes can therefore be seen as a tool serving both the economy and society through providing participation for the people, and at the same time combating social exclusion. The objective within these programmes is in essence to support the social cohesion among the Member States which is not an easy process within the EU project.

Although education and cultural policy areas are considered as low politic areas, within the EU project they can not be regarded as less important as they should not be seen as fields covering only education and cultural matters. It is obvious and important that, for further and deeper integration of the EU, there has to be cohesion among the people of the Member States if the EU is to be or willing to be a global actor. This, however can only be reached both by enhancing the harmonization of the societies and people and by working towards closing the gap between the institutions and the citizens of the EU. This situation has even become more important with the recent two enlargements of the EU. Including most of the Central and Eastern European Countries, social and economic diversity within the EU has been considerably increased.

To achieve the goal of integrating these societies with each other under the principle of unity in diversity, the education and cultural policy areas are gaining more and more importance parallel with the further enlargement plans of the EU regardless of deepening versus widening questions as well as its new digestion criteria. To put it simply, at present it seems that both education and cultural policies lie at the heart of the discussions for the future of the EU.

\section{References:}

Bozoki, Andras. "Cultural Policy and Politics in the European Union", speech by Minister of Education of Hungary, 1-16. Retrieved: 10.02.2007 from http://137.204.115.130/activities/download/Bozoki/ Cultural\%20Policy\%20and\%20Politics\%20in\%20the\%20European $\% 20$ Union.pdf.

Bulletin of the European Communities, A people's Europe, Report from the 
ad hoc Committee, Supplement $7 / 85$, Office for Official Publications of the European Communities 1985. Luxembourg.

Campbell, David E. (2006) "What is education's impact on civic and social engagement? Measuring the effects of education on health and civic engagement", Proceedings of the Copenhagen symposium; 25-126. Retrieved: 05.03 .2007 , from http://www.oecd.org/dataoecd/14/63/ 37425694.pdf.

Checkel, Jeffrey T. (1998) "The Constructivist Turn in International Relations Theory”, World Politics 50.2; 324- 348.

Chugina, Margarita Kol. (2006) "International Integration in Higher Education", Russian Politics and Law, Vol. 44, No. 4; 23-44. Retrieved: 22.05.2007, from http://mesharpe.metapress.com/app/home/contri bution.asp?referrer=parent\&backto=issue,3,6;journal,4,19;linkingpublica tionresults, 1:110919,1.

Cornwall Compact, (2006) "Voluntary and Public Sector Agreement, Diversity, including Black and Minority, Ethnic Groups, Code of Good Practice". Retrieved: 11.03.2007, from http://www.restormel.gov.uk/ media/adobe/l/b/Diversity_Code_of_Good_Practice_1_1.pdf.

Corbett, Anne. (2005) Universities and the Europe of Knowledge Ideas, Institutions and Policy Entrepreneurship in European Union Higher Education Policy, 1955-2005, Palgrave Macmillan, New York.

Delanty, Gerard. (2006) "Cultural Pluralism, Social Justice and the Idea of a European Commonwealth",(ISPI) Working Papers, WP-8; 2-27. Retrieved: 15.04.2007, from http://www.ispionline.it/it/documents/wp _8_2006.pdf.

Euro barometer Series by the Gallup Organization, (2007). Young Europeans, A survey among young people aged between 15-30 in the EU, No: 202 - Youth Survey Analytical Report. Retrieved: 13.06.2007, from http://ec.europa.eu/public_opinion/flash/fl_202_en.pdf

European Commission (1995) White Paper on Education and Training,

Teaching and Learning, Towards the Learning Society. Retrieved: 16.06.2007, from http://europa.eu/documents/comm/white_papers/pdf/com95_590_en.pdf (1996) 'Report on the Consideration of Cultural Aspects in European Community Action' COM (1996) 160, 17.04.1996. Brussels. 
(2001) 'Making a European Area of lifelong Learning a reality', COM (2001) 678, 21.11.01. Brussels. (2005) 'New Programme for the period 2007-2013 to promote active European citizenship: 'Citizens for Europe', SEC (2005) 442, 6.4.2005. Brussels.

European Council, Declaration on European Identity, Meeting in Copenhagen on 14 and 15 December 1973, Bull. EC 11-1973, the Heads of State or Government of the nine Member States of the enlarged European Community, Annex 11. Retrieved: 20.04.2007, from http://aei.pitt.edu/1439/01/copenhagen_1973.pdf.

Field, John. (1998) European Dimensions, Education, Training and the European Union, Higher Education Policy Series 39, Jessica Kingsley Publishers, London.

Ifversen, Jan. (2002) " Europe and European Culture - A Conceptual Analysis", European Societies, Vol.4 No 1; 1- 26. Retrieved: 25.05.2007, from http://person.au.dk/da/pub/24039?id=8452

Lawn, Martin. (2003) "The 'Usefulness' of Learning: the struggle over governance, meaning and the European education space', Discourse: studies in the cultural politics of education Vol. 24, No. 3; 325-326. Retrieved: 22.12.2006, from $\mathrm{http}: / /$ www.informaworld.com/smpp/content $\sim$ content $=\mathrm{a} 713618455 \sim \mathrm{db}=$ all

Monnier, Alain. (2004) "The European Union at the Time of Enlargement", translated by Godfrey I. Rogers, Population- E Vol. 59, No. 2; 315-336. Retrieved: 10.06.2007, from http://www.ined.fr/fichier/t_telechargement/7189/telechargement_fichier _en_publi_pdf2_monniere.pdf

Official Journal of the European Communities (2000) Decision of the European Parliament and of the Council amending Decision No 508/ $2000 /$ EC of 14 February establishing the "Culture 2000" programme, L61/1. Retrieved: 18.04.2007, from http://eurlex.europa.eu/LexUriServ/LexUriServ.do?uri=OJ:L:2000:063:0001:0009 :EN:PDF

Oğuzkan, Turhan. (1997) Educational Systems: An Introduction to Structures and Functions, Boğaziçi University Publications, İstanbul.

Prague Communiqué, Meeting of European Ministers in charge of higher education, Towards the European Higher Education Area, Prague, May 
19, 2001. Retrieved: 17.02.2007, from http://www.bolognaberlin2003.de/pdf/Communiquel.pdf

Radaelli, Claudio M. (2003) "The Open Method of Coordination, A new governance architecture for the European Union?'" Swedish Institute for European Policy Studies (Sieps). Retrieved: 02.03.2007, from http://www.eurosfaire.prd.fr/7pc/doc/1168434892_cr20031.pdf

Sassatelli, Monica. (2002) "Imangined Europe: The Shaping of a Euopean Cultural Identity through EU Cultural Policy", European Journal of Social Theory, 5 (4): 435-451

Seidendorf, Stefan. (2003) "Europeanisation of National Identity Discourses? Comparing French and German Print Media", European Consortium for Political Research- ECPR, Joint Sessions of Workshops, $28^{\text {th }}$ March $-2^{\text {nd }}$ April.

Shore, Cris. (2006) 'In uno plures'(?) EU Cultural Policy and the Governance of Europe", Cultural Analysis 5:7-26.

Shore, Cris. (2004) "Whither European Citizenship? Eros and Civilization Revisited', European Journal of Social Theory, 7 (1):27-44

Solemn Declaration on European Union, European Council Stuttgart 19 June 1983, Reproduced from the Bulletin of the European Communities, No 6/1983. Retrieved: 14.03.2007, from http://aei.pitt.edu/1788/01/stuttgart_declaration_1983.pdf

Spoonley, Paul. , Robin Peace, Andrew Butcher, Damian O'Neill (2005) "Social Cohesion: A Policy and Indicator Framework for Assessing Immigrant and Host Outcomes", Social Policy Journal of New Zealand; 85-110. Retrieved: $19.10 .2006, \quad$ from http://www.msd.govt.nz/documents/publications/msd/journal/issue24/24 -pages85-110.pdf

The Treaty of Amsterdam, Articles 6a - 129a. Retrieved: 20.04.2007, from http://www.eurotreaties.com/amsterdamtreaty.pdf

Treaty on the European Union, Citizenship of the Union, Provisions amending the Treaty establishing the European Economic Community with a view to establishing the European Community, Article 8. Retrieved: 18.04.2007, from http://www.eurotreaties.com/maastrichtec.pdf

Treaty on the European Union, Title IX, Article 128 retrieved from; The Treaty on European Union, Official Journal of the European Union, C 
191, 29 July 1992. Retrieved: 11.03.2007, from http://europa.eu.int/eurlex/en/treaties/dat/EU_treaty.html

Treaty on the European Union, Articles 149- 150. Retrieved: 13.12.2006, from http://www.eurotreaties.com/maastrichtec.pdf

Walkenhorst, Heiko. (2005) "The Changing Role of the EU Education Policy- a critical Assessment", Paper for the EUSA Ninth Biennial International Conference, Austin, Texas. Retrieved: 07.04.2007, from http://aei.pitt.edu/3177/01/Walkenhorst_EUSA_2005_final.pdf

Yero, Judith Lloyd. (2001-2002) “The Meaning of Education", Teachers Mind Resources Website. Retrieved: 09.10.2006, from http://www.teachersmind.com/pdfdirectory/Education.PDF 